\title{
Constraining the subsurface geochemical baseline of CMC Research Institutes' Field Research Station (FRS), Alberta
}

\author{
RACHEL UtLEY ${ }^{1}$, NiCHOLAS UTTING ${ }^{2}$, GARETH \\ JOHNSON $^{3}$, MARTA ZURAKOWSKA ${ }^{4}$, DOMOKOS \\ GYÖRE ${ }^{4}$, FINLAY STUART ${ }^{4}$, KIRK OSADETZ ${ }^{5}$, \\ THOMAS DARRAH ${ }^{6}$, R. STUART HASZELDINE ${ }^{1}$, \\ STUART GILFILLAN ${ }^{1 *}$
}

${ }^{1}$ School of GeoSciences, University of Edinburgh, Grant Institute, James Hutton Road, Edinburgh EH9 3FE, UK ${ }^{2}$ Natural Resources Canada, CanmetENERGY, 1 Oil Patch Drive Devon, Alberta, T9G 1A8, Canada

${ }^{3}$ Department of Civil and Environmental Engineering, University of Strathclyde, Glasgow, G1 1XJ, UK

${ }^{4}$ Isotope Geosciences, SUERC, East Kilbride G75 0QF, UK ${ }^{5} \mathrm{CMC}$ Research Intitutes Inc., 3535 Research Way NW, Calgary, Alberta, AB T2L 2K8 Canada

${ }^{6}$ School of Earth Sciences, The Ohio State University, Columbus, Ohio 43210 United States

*Correspondence: stuart.gilfillan@ed.ac.uk

Geochemical monitoring can verify secure $\mathrm{CO}_{2}$ storage and detect unplanned $\mathrm{CO}_{2}$ migration. A robust geochemical baseline is needed prior to subsurface $\mathrm{CO}_{2}$ injection. We present the first multi-well gas and groundwater geochemical baseline characterisation at CMC Research Institutes' Field Research Station (FRS) in Alberta.

We confirm that $\mathrm{CH}_{4}$ occurs pervasively in the shallow $(<550 \mathrm{~m})$ Upper Cretaceous bedrock succession. Using $\mathrm{C}_{1} / \mathrm{C}_{2}+\mathrm{C}_{3}$ ratios, $\delta^{13} \mathrm{C}_{\mathrm{CH}}, \delta \mathrm{D}_{\mathrm{CH} 4}$ we determine that the $\mathrm{CH}_{4}$ is primarily of biogenic origin. However, we also identify a small, but resolvable $(1-15 \%)$, thermogenic $\mathrm{CH}_{4}$ component that increases with depth, which is correlated with increasing radiogenic-sourced ${ }^{4} \mathrm{He}$.

Measured ${ }^{4} \mathrm{He}$ concentrations exceed those that could be generated by in-situ radioactive decay of $U$ and $T h$ in the host Upper Cretaceous stratigraphy. ${ }^{4} \mathrm{He}$ concentrations lie on a mixing line between the atmosphere and a nearby petroleum well that produces natural gas from Lower Cretaceous Viking Fm. This excess ${ }^{4} \mathrm{He}$ could indicate mixing with a radiogenic component that is consistent with observed elevated nucleogenic and radiogenic-derived ${ }^{21} \mathrm{Ne}^{*}$ and ${ }^{40} \mathrm{Ar} *$ present in several gas samples.

In contrast to previous work, this indicates a small, but resolvable crustal contribution to the subsurface fluids at the FRS site, showing that a fluid connection from the petroleum producing Viking Fm. is present in this portion of the Western Canada Sedimentary Basin. 